\title{
Oxidative stress and immunologic responses following a dietary exposure to PAHs in Mya arenaria Nicolas Pichaud ${ }^{1}$, Jocelyne Pellerin*1, Michel Fournier ${ }^{1,2}$, Sophie Gauthier- Clerc $^{2}$, Pascal Rioux ${ }^{1}$ and Émilien Pelletier ${ }^{1}$
}

Address: ${ }^{1}$ Institut des Sciences de la Mer de Rimouski, 310 Allée des Ursulines, Rimouski (Québec), G5L 3A1, Canada and 2INRS- Institut ArmandFrappier, 531 Boul. des Prairies, Laval (Québec), H7V 1B7, Canada

Email: Nicolas Pichaud - pichaud.nicolas@wanadoo.fr; Jocelyne Pellerin* - jocelyne_pellerin@uqar.qc.ca;

Michel Fournier - michel.fournier@iaf.inrs.ca; Sophie Gauthier-Clerc - sophie.gauthier-clerc@partenaires.mapaq.gouv.qc.ca;

Pascal Rioux - pascal_rioux@uqar.qc.ca; Émilien Pelletier - emilien_pelletier@uqar.qc.ca

* Corresponding author

Published: 2 December 2008

Chemistry Central Journal 2008, 2:23 doi:10.1 186/1752-153X-2-23

This article is available from: http://journal.chemistrycentral.com/content/2/1/23

(C) 2008 Pichaud et al
Received: 9 September 2008

Accepted: 2 December 2008

\begin{abstract}
Background: The aim of this research was to investigate oxidative stress and immune responses following a dietary polycyclic aromatic hydrocarbon (PAH) exposure in a marine bioindicator organism, the soft shell clam, Mya arenaria. Immune parameters in hemolymph (haemocyte number, efficiency of phagocytosis and haemocyte activity) and assessment of oxidative stress using catalase (CAT) activity and levels of malondialdehyde (MDA) performed on the digestive gland were estimated as biomarkers in clams fed in mesocosm with PAH contaminated phytoplankton. MDA levels and CAT activities were also measured in situ in organisms sampled in a control site (Metis Beach, Québec, Canada) as well as organisms sampled in a site receiving domestic effluents (Pointeau-Père, Québec, Canada), to assess effects of abiotic variables related to seasonal variations and mixed contamination on the selected parameters.
\end{abstract}

Results: Results on immune parameters suggest that the PAHs may interfere with the maturation and/or differentiation processes of haemocytes. MDA results showed that lipid peroxidation did not occur following the exposure. The levels of CAT activity corresponded to weak antioxidant activity (no significant differences). Recovery was noted for all the immune endpoints at the end of the experiment.

Conclusion: Results suggest that immune parameters are early biomarkers that can efficiently detect a physiological change during a short term exposure to low concentrations of PAHs. The in situ survey (in the natural environment) suggested that clams from the Pointe-au-Père site did not show any oxidative stress as well as the clams contaminated in mesocosm, probably due to the low concentrations of PAHs used for this study. MDA levels increased however in organisms from Metis Beach, a response probably related to domestic effluents or parasitism.

\section{Background}

Polycyclic Aromatic Hydrocarbons (PAHs) are ubiquitous in the environment. They are produced by incomplete combustion of solid and liquid fuels. High molecular weight PAHs are predominantly adsorbed on soot and particulate matter before being transported in aquatic environment. According to environmental conditions, they may accumulate in sediments [1]. Bioavailability to 
marine organisms is a consequence of different mechanisms such as bioturbation, sediment resuspension and diffusion. Bivalve molluscs are suitable species to assess toxicity in the environment due to their sedentary nature, filter-feeding behavior and ability to bioaccumulate pollutants like PAHs [2-5].

Exposure to PAHs can lead to toxic effects in Mytilus edulis [5-10], Mytilus galloprovincialis [11,12], Unio tumidus [13], Mya truncata [14] and Perna viridis [15,16]. At cellular and molecular levels, exposure to PAHs may also trigger responses of biomarkers. For instance PAHs increase the formation of Reactive Oxygen Species (ROS) and induce detoxification systems like antioxidant defense systems present in all aerobic cells [11,17-20]. Therefore, monitoring of adverse effects as well as modifications of cellular and molecular defense systems can both be used as biomarkers $[9,16,21,22]$.

Different antioxidant parameters, like the antioxidative enzymes including superoxide dismutase, glutathion peroxidase and catalase (CAT), are commonly used to assess exposure to xenobiotics in animals. Particularly, CAT is an enzyme promoting the conversion of hydrogen peroxide $\left(\mathrm{H}_{2} \mathrm{O}_{2}\right)$ to water and molecular oxygen and can be used as a biomarker of oxidative stress in bivalves. A number of studies reported an increase of superoxide dismutase and CAT activities when an excess of ROS was observed in bivalves $[16,23]$. Lipid peroxidation attesting membrane damage was noticed when the antioxidant defenses were the lowest [24-27]. Malondialdehyde (MDA) is one of the final products of the membrane fatty acid degradation, mainly total thiobarbituric acid-reactive substances (TBARS), and is considered as a good biomarker of lipid peroxidation and consequently of oxidative stress $[15,16,23]$. The presence of pollutants in the environment increases CAT activity and MDA level in bivalves $[13,21]$. More specifically, exposure to PAH contaminated sediments showed the same trend in Mytilus galloprovincialis [28], Mytilus edulis [29] and Perna viridis [16].

The immune system is a sensitive target to the toxic action of chemicals in several organisms [19,30-32]. In bivalves, haemocytes and phagocytosis are the main components of the immune system [20,33]. An increase in the number of haemocytes has been observed after TBT contamination in Crassostrea virginica [34] and fluoranthene in Mytilus edulis [35]. However, a reduction in haemocyte count was observed with high concentrations of copper in Sunetta scripta and Villorita cyprinoides var. cochinensis [36]. Sediment contaminated by PAHs led to a decreased number of haemocytes and inhibited phagocytic activity in exposed Crassostrea virginica [37] and Mytilus edulis $[2,3]$. These responses were dependent on the species and the type of contaminant studied even if concentrations were much higher (more than $500 \mu \mathrm{g}$ per litre per day) [2] than those found in the contaminated environment $[2,32,37]$. It is therefore of first importance to determine the sensitivity of immune endpoints as good markers of exposure to PAHs in bivalves. Considering antioxidant responses induced following an exposure to PAHs and the consequences on immune competence, it is also crucial to study interaction between the PAHs exposure and the physiological state of the organism.

Due to their lipophilic nature, PAHs are present in the entire marine coastal food web and we aimed in the present work to study effects of dietary exposure to PAHs on immune parameters and oxidative stress in Mya arenaria. It represents the first level of contamination via the trophic way, and may be of real importance in complement to other trophic level contamination studies to better understand the bioaccumulation process.

CAT activities and MDA levels were also surveyed in field animals (in situ experiments) to assess their natural level. Immune parameters were not measured in these organisms due to the rapid deterioration and the difficulty to preserve the haemolymph.

This work is a contribution to a crucial need to understand physiological responses of marine invertebrates facing toxicant challenges and eventually a decrease of their health conditions and survival rate.

\section{Results and discussion Effects of PAHs exposure on cell viability and haemocyte count}

Viability of haemocytes was above $98 \%$ for both control and contaminated groups and for all samplings. For haemocyte counts (Fig. 1), a significant reduction in the number of haemocytes was observed at days $9(\mathrm{P}=0.019)$ and $17(\mathrm{P}=0.004)$. For the last day of the experiment, the number of haemocytes in contaminated clams was not different from the number of haemocytes in control clams with a ratio near one.

\section{Effects of PAHs exposure on phagocytosis}

Phagocytic activity representing the percentage of haemocytes having engulfed one bead or more is illustrated in Fig. 2. A significant inhibition of phagocytosis was observed for contaminated clams at days $2(\mathrm{P}=<0.001)$ and $9(P=<0.001)$ during the contamination and at day $17(\mathrm{P}=<0.001), 8$ days after the beginning of the depuration process. Fig. 3 shows efficiency of phagocytic cells represented by the percentage of cells having engulfed three beads or more. There was a significant decrease of efficiency of phagocytic cells in contaminated organisms at days $2(\mathrm{P}=<0.001), 9(\mathrm{P}=<0.001)$ and $17(\mathrm{P}=<$ $0.001)$. At the end of the experiment, the phagocytic activ- 


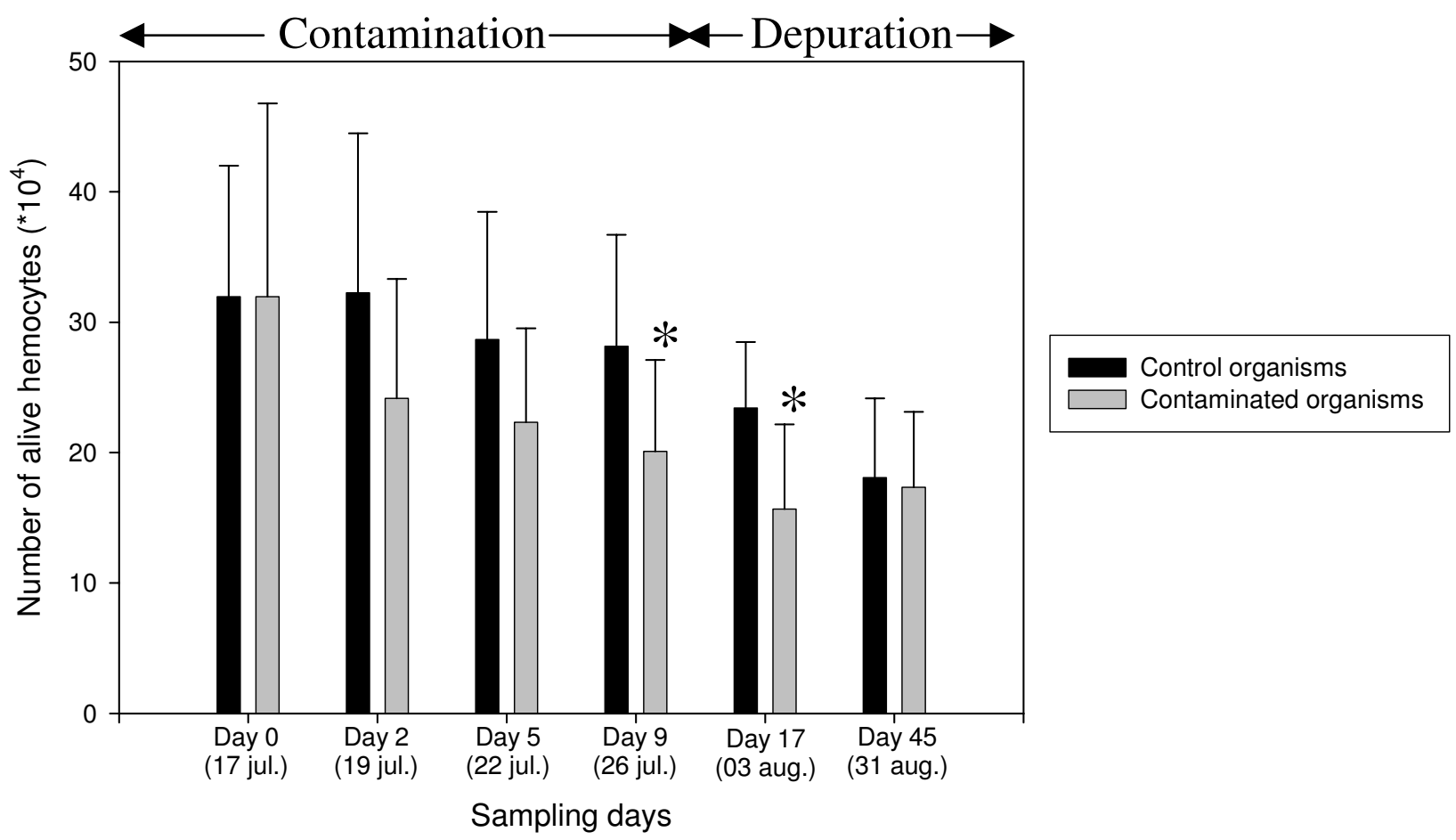

Figure I

Effects of dietary exposure to PAHs on the number of hemocytes. Results are expressed as the mean number of live hemocytes $\left(10^{4}\right)$ per 12 clams, in hemolymph collected from control and contaminated organisms. Organisms were exposed to $\mathrm{PAH}$ s during 9 days and the contamination was stopped for the remaining 36 days. Significant differences between control and contaminated clams are represented by $*$ for $P<0,05$. Error bars represent S.E.M.

ity of contaminated clams returned to the same level than the controls.

\section{Biochemical markers}

CAT activity following PAHs exposure showed no significant differences between control and contaminated organisms (results not shown). In both groups, significant differences were observed between days of the experiment. Differences were observed between the first day and the fifth day and between the first day and the end of the exposure period when a general increase of CAT activity in controls and contaminated organisms were observed due to uncontrolled introduction of air under high pressure during the fifth day (see "Exposure protocol").

Lipid peroxidation assessed by the MDA levels showed no significant differences (results not shown).

Samples from Pointe-au-Père and Metis beach showed no significant differences for CAT. The levels of CAT activity were similar for both sites (data not shown).
For MDA level, among 11 sampling days, 8 of them showed significant differences between sites (Fig. 4). Levels were significantly higher in the site of Metis during sampling days 2 ( $1^{\text {st June) }}$ (Kruskal-Wallis test, $\mathrm{H}=6,604$, $\mathrm{P}=0,01), 3$ (15 th June) (Kruskal-Wallis test, $\mathrm{H}=15,384$, $\mathrm{P}=<0,001), 4$ (30 th June $)(\mathrm{P}=<0,001), 6\left(28^{\text {th }}\right.$ July) ( $\mathrm{P}$ $=<0,001), 7$ (10 August) (Kruskal-Wallis test, $\mathrm{H}=$ $14,963, P=<0,001), 9\left(12^{\text {th }}\right.$ September $)(P=<0,001)$ and 11 (4 $^{\text {th }}$ October) (Kruskal-Wallis test, $\mathrm{H}=27,539, \mathrm{P}=<$ 0,001). For 26 $6^{\text {th }}$ August (sample 8), levels at Metis were significantly lower than in Pointe-au-Père $(P=<0,001)$.

No correlations were found using the Pearson's coefficient between PAH exposure and the biomarker responses measured for both mesocosm and in situ organisms, i.e. that there was no linear relationship between these two variables.

An increase in the number of circulating haemocytes is commonly observed in bivalves after an exposure to a large variety of environmental stressors or toxic sub- 


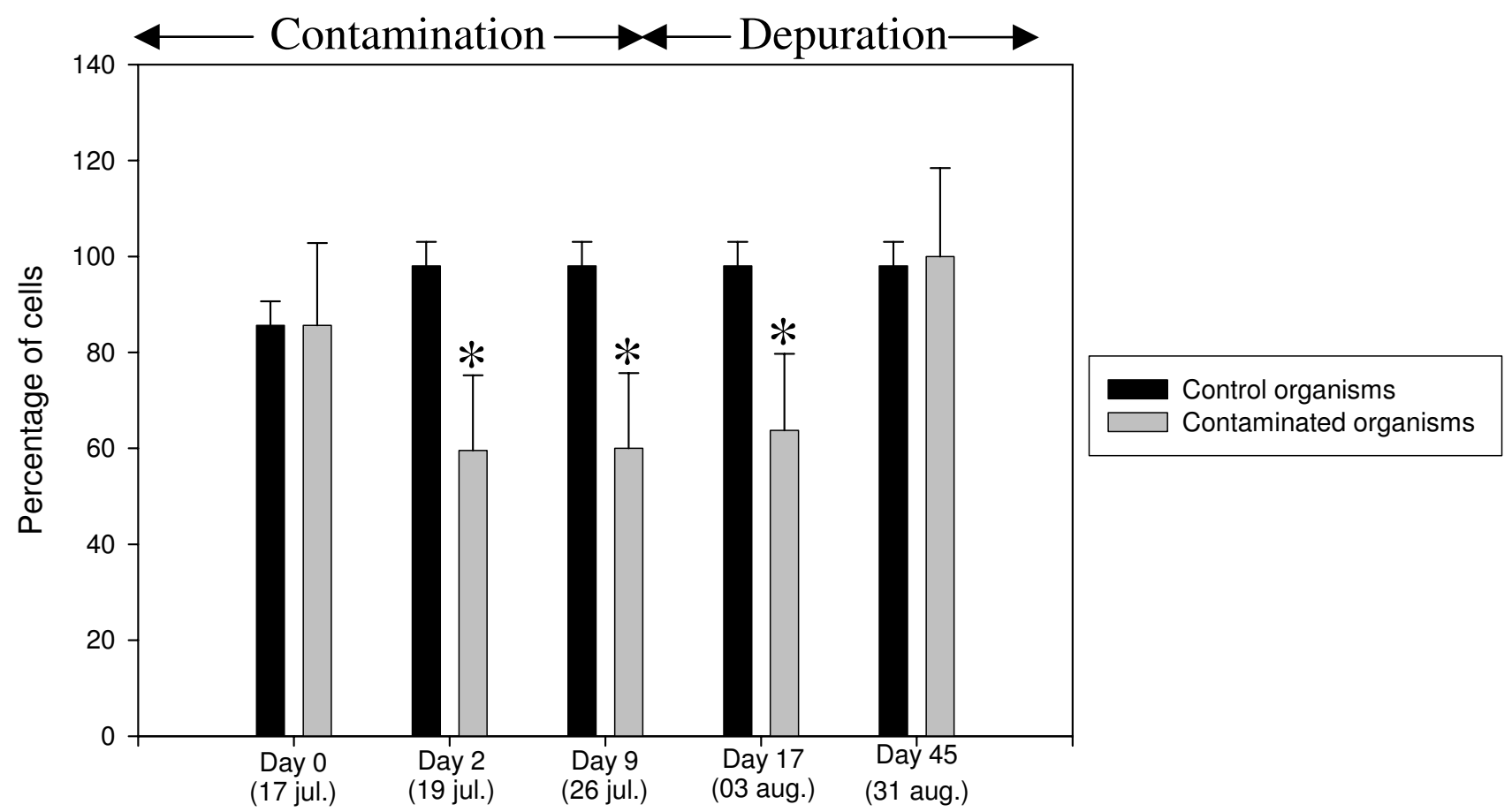

Sampling days

Figure 2

Effects of exposure to PAHs on phagocytic activity of haemocytes. Results are expressed as percentage of haemocytes, collected from Mya arenaria, having engulfed one bead or more. Organisms were exposed to PAHs during 9 days and the contamination was stopped for the remaining 36 days. Significant differences between control and contaminated clams are represented by $*$ for $P<0,05$. Error bars represent S.E.M.

stances [34,35,38,39]. However, other studies have reported a decrease in haemocyte counts, but for levels of contaminants not found in natural environment [2]. Sami et al. [37] have shown that the count of haemocytes from American oyster Crassostrea virginica could be modulated following in situ exposure to PAHs. In the present study, significant decreases were observed in days 9 and 17 between the count of haemocytes in control and contaminated organisms while no significant differences were detected between controls and contaminated at the beginning of the experiment. A slight decrease appeared during the exposure at contamination level similar to the environmental levels. The haemocyte number continued to decrease at day 17 in contaminated animals even if the exposure was stopped at the ninth day.

A significant decrease was also observed for control organisms from day 17 to the end of the experiment. For the last day of the experiment, the number of circulating haemocytes was lower comparatively to the other sampling days but similar for both groups. PAHs could possibly have affected directly the production of haemocytes in Mya are- naria. Organisms were sampled in June where a large majority of individuals were in spawning (spermatozoids only visible in the center of the alveoli and lower number of ripe oocytes free in the alveoli) stages (56,5\% and $43,2 \%$ for males and females respectively) and in spent or past (no visible spermatogonia or oogonia) stages $(39,1 \%$ and $43,2 \%$ for males and females respectively) in Mya arenaria from the site of Metis Beach [40]. However, mesocosm experiments were conducted from mid July to the end of August where clams were in indifferent (no visible spermatogonia) stages for males $(88,5 \%)$ and in indifferent and previtellogenic (no visible oogonia and small oogonia at the periphery of the alveoli respectively) stages for females $(42,4 \%$ and $36,4 \%$ respectively) [40]. These observations led us to presume that PAHs were not being sequestered/partitioned into developped ovaries and so were available to the haemocytes because clams had already spawned. However, we could suspect that the decrease of the number of circulating haemocytes in control clams was due to a few individuals that did not spawn. 


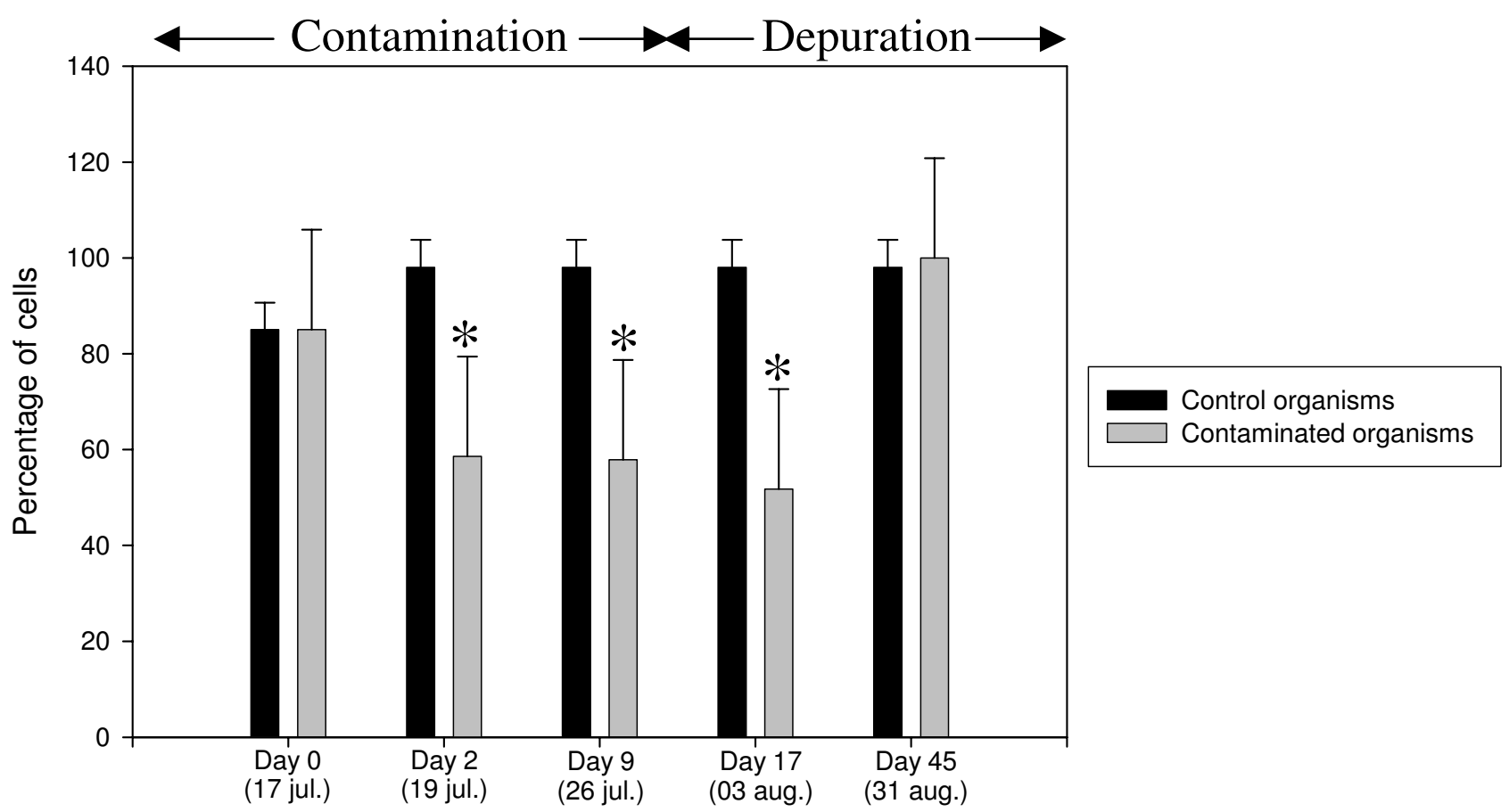

Sampling days

\section{Figure 3}

Effects of exposure to PAHs on the efficiency of phagocytic cells. Results are expressed as percentage of haemocytes, collected from Mya arenaria, having engulfed three beads or more. Organisms were exposed to PAHs during 9 days and the contamination was stopped for the remaining 36 days. Significant differences between control and contaminated clams are represented by $*$ for $\mathrm{P}<0,05$. Error bars represent S.E.M.

Phagocytosis in bivalves exposed to PAHs tended to decrease with increasing concentrations of contaminants $[2,3,5,41,42]$. PAH exposure has been shown to significantly suppress phagocytic activity in Mytilus edulis [2,3], Mya arenaria and Mactromeris polynyma [32]. However, long-term exposure to benzo-(a)-pyrene slightly stimulated phagocytic activity in Mercenaria mercenaria [41]. Moreover, exposure to low concentrations of PAHs may stimulate phagocytic activity whereas increasing levels could suppress phagocytosis in Mya arenaria [32,43,44]. In this work, a significant difference was observed just after the beginning of the contamination showing the acute effects of PAHs on haemocyte activity (cells having engulfed one bead or more) and on the efficiency of phagocytosis (cells having engulfed three beads or more), this threshold assessing the more active population of haemocytes in phagocytosis [19,20,43-45].

There were significant differences in phagocytosis between controls and contaminated clams at days 9 and 17. Day 45 showed a return to initial conditions with a percentage of cells having engulfed one bead or more and three beads or more near to $100 \%$ attesting their great efficiency. This trend showed a strong recovery of clams. PAHs caused phagocytic inhibition at concentrations near those reported in the environment. As phagocytosis is a membrane-dependent process, PAHs affected directly the membrane stability resulting in physical disturbance of the lysosome membrane and further disrupted immune function. Other studies have already demonstrated this reduction in the lysosomal membrane stability of haemocytes of bivalves species like Mytilus edulis [2,3,46] and Mya arenaria [32,43], associated with the inhibition of phagocytic activity. PAHs may also interfere within the maturation and/or differentiation processes of haemocytes [43]. Recovery of the immune function in Mya arenaria during the depuration process showed that the effects of PAHs at concentrations used for this experiment were reversible.

PAHs are known to increase production of ROS leading to oxidative stress $[47,48]$. Oxidative stress results in increased levels of CAT activity, an antioxidant enzyme used by the organism to detoxify cells [23]. This oxidative 


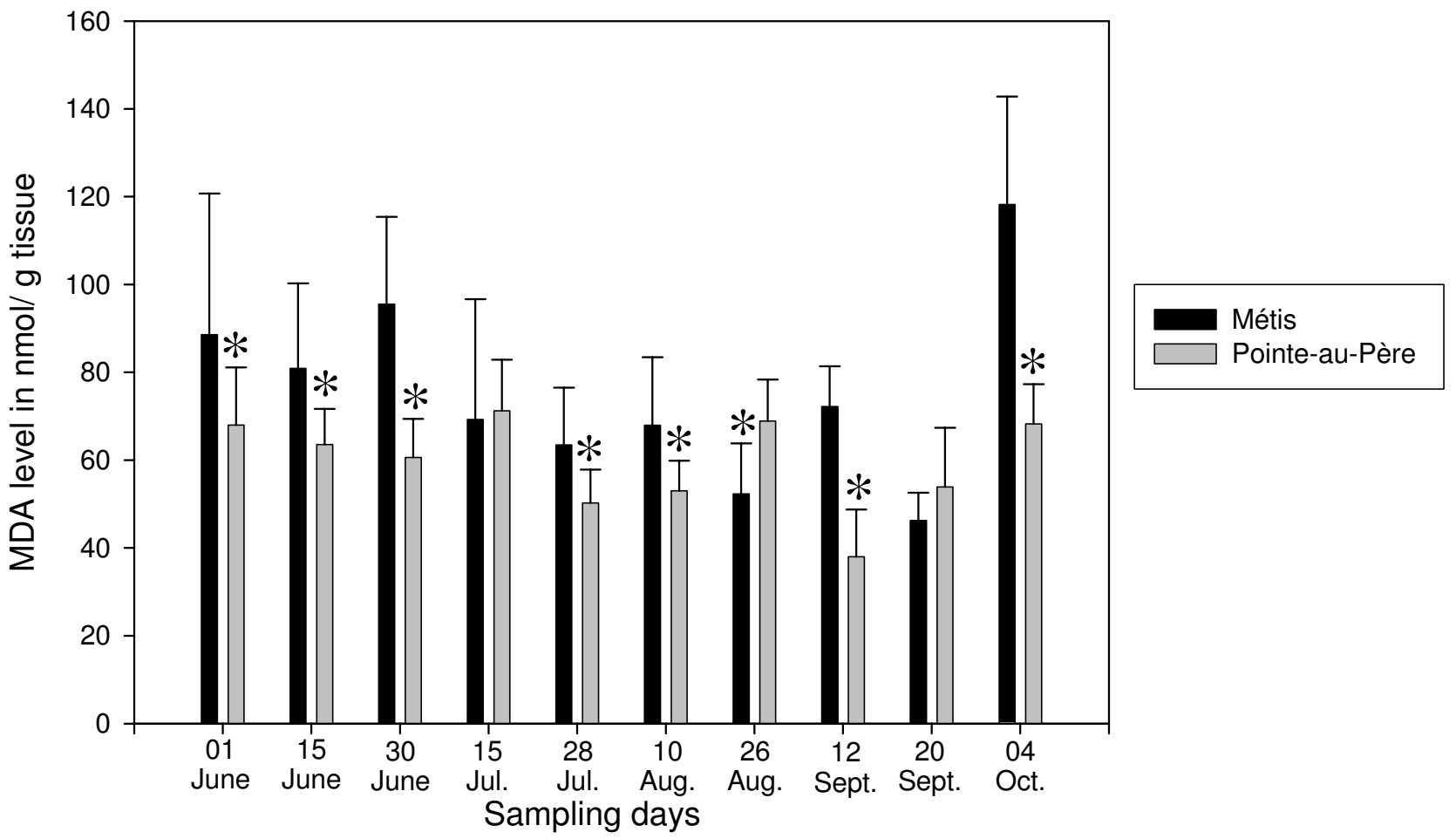

Figure 4

MDA levels in the digestive gland of Mya arenaria sampled in natural environment (in situ survey). Results are expressed as nmol per $\mathrm{g}$ tissue. Significant differences between control and contaminated clams are represented by $*$ for $\mathrm{P}<$ 0,05. Error bars represent S.E.M.

stress can lead to cell damage caused by lipid peroxidation that can be assessed by the level of MDA [13,21]. In bivalves, several studies have associated the antioxidant activity with a contamination by PAHs [16,25,29]. For this work, the experiment showed no significant differences between control and contaminated organisms. The activity of the antioxidant system represented by CAT was constant under stress induced by the PAH exposure, probably because the PAHs concentration used for this experiment was similar to environmental conditions (the same concentration detected in seawater from the Pointe-auPère site, representative of the St. Lawrence-Saguenay system). CAT responses were therefore indicative in this study of a no-stress exposure. Nevertheless, further studies have showed that PAHs were effectively incorporated in clams after exposure by a trophic way and that radioactive pyrene had a 14-day residence time [49]. Since no increased CAT activity was observed, another antioxidant system may be involved. An increase in the level of the superoxide dismutase enzyme was observed in bivalves as well as for CAT after an exposure to PAHs [25,29]. Moreover, the superoxide dismutase works in association with the CAT, both of them showing the same trend. This result suggests that glutathione peroxidase was used to detoxify cells in presence of this complex mixture of PAHs.
MDA concentration increases generally when stress overwhelms the antioxidant systems [50]. However, no significant differences were detected between control and contaminated organisms. The levels of CAT remaining during the exposure experiment confirmed that no oxidative stress was detected and consequently no oxidative damages to polyunsaturated fatty acids. Moreover, results of the immune parameters measured attested the hypothesis of the membrane destabilisation or of interference within the maturation and/or differentiation processes of haemocytes caused by PAH contamination. This suggests that phagocytic activity and haemocyte number, comparatively to CAT activity and MDA level, is an early biomarker that is really efficient to detect a physiological change during a short term exposure to xenobiotics like PAHs at low concentrations. There was low bioaccumulation measured in organisms $(<2 \mathrm{nmol} / \mathrm{g}$ dry weight of total PAHs including phenanthrene, anthracene, fluoranthene, pyrene and benzo(a)pyrene in soft tissues) during all the experiment period reaching a maximum of $1,15 \mathrm{nmol} / \mathrm{g}$ of dry weight $\pm 0,42$ at the $30^{\text {th }}$ day during the depuration, due to the low and realistic concentrations used for the exposure. PAHs generally do not bioaccumulate in tissues or at a really low rate. However, PAHs can cause a variety of deleterious effects in exposed animals since some PAH 
metabolites that are intermediates in the process of detoxication have carcinogenic, mutagenic and cytotoxic activities $[51,52]$.

For comparison purposes between Metis and Pointe-auPère sites, CAT activity showed no significant differences. However, when compared with data of the mesocosm experiment, the mean of CAT activity values were lower in the field study. Clams exposed to PAHs in mesocosm showed a CAT activity of $90.97 \mathrm{nmol} / \mathrm{min} / \mathrm{mg}$ proteins while clams from Pointe-au-Père showed a CAT activity of $92.47 \mathrm{nmol} / \mathrm{min} / \mathrm{mg}$ proteins. Interestingly, control organisms in the exposure experiment had a CAT activity of $87.87 \mathrm{nmol} / \mathrm{min} / \mathrm{mg}$ protein while CAT activity of organisms from Metis was of $94.19 \mathrm{nmol} / \mathrm{min} / \mathrm{mg}$ protein. The results from Pointe-au-Père clams and from clams contaminated in mesocosms showed that with a PAHs concentration near the environmental concentration detected in the St. Lawrence-Saguenay system, no oxidative stress was observed. At low concentrations, PAHs have no effects on the antioxidant enzymes such as CAT and on the lipid peroxidation assessed by MDA level of filter-feeding bivalves such as Mya arenaria. Moreover, clams from the two sites were exposed to changes in natural conditions such as air exposure, temperature, tide cycling and sunshine, which can cause an increase of CAT activity in bivalves [23], in contrast to the stable conditions in aquaria during the exposure experiment. These environmental changes can explain the relative differences between mesocosm and field organisms. MDA levels were significantly higher in Metis than in Pointe-au-Père for 7 samplings attesting a greater lipid peroxidation. In the site of Pointe-au-Père, no contamination effects of PAHs appeared from our results comparatively to Metis, except on $26^{\text {th }}$ August where MDA levels in Metis were significantly lower probably because sampling occured when the site was partially immersed due to the tidal period. Higher levels of MDA levels in Metis can be explained by the fact that some clams can be infected by a castrator trematode Prosorhyncus squamatus. This parasite was observed in few clams from Metis but was not seen in clams from Pointe-au-Père [53]. Parasites are known to be major stressors for aquatic organism [54] and among them, P. squamatus could inhibit gonadial mitosis in Mya arenaria [53] Mytilus edulis, Mytilus galloprovincialis, Pecten maximus and Ostrea edulis $[55,56]$ and therefore could trigger lipid peroxidation.

\section{Experimental}

\section{Experimental design}

In June 2004, sediment and soft shell clams (Mya arenaria) were collected on the south shore of the St. Lawrence Estuary, in Metis Beach $\left(48^{\circ} 40^{\prime} \mathrm{N}, 68^{\circ} 00^{\prime} \mathrm{W}\right)$, a site exempt of direct sewage inputs or harbor activity [32]. Organisms were randomly sampled at low tide and ranged between 55 and $65 \mathrm{~mm}$ in shell length. Sediments were taken in the first $10 \mathrm{~cm}$ and sieved through a $1 \mathrm{~mm}$ mesh array. Clean sediments were divided in 10 aquaria of $65 \mathrm{~L}$ (containing $1 / 3$ of sediments and $2 / 3$ of water) and supplied with seawater at a constant flow rate of 500 $\mathrm{mL}$ per min to maintain a good renewal rate. Salinity and temperature were maintained at 28 to $30 \mathrm{ppm}$ and 8 to $10^{\circ} \mathrm{C}$ respectively, reflecting the environmental parameters at this specific site. Organisms $(n=36$ per aquarium $)$ were transferred in each aquarium 14 days prior to the beginning of the experiment, to reduce the stress due to handling. Population density of Mya arenaria was of 200 clams per $\mathrm{m}^{2}$ in each aquarium. Densities of clams are highly variable throughout the world $(2-2,000$ clams per $\mathrm{m}^{2}$ and between 10 to 200 clams per $\mathrm{m}^{2}$ in the SaguenaySt. Lawrence system) since clams can settle in various substrates, some of them are more favourable to the settlement of a high number of juvenile clams [57-59]. Clams were fed during the last week of the acclimation period with phytoplankton Asterionnella diluted in seawater filtered with a $0.7 \mu \mathrm{m}$ membrane. Algae concentration was of 20 million cells per $\mathrm{mL}$ with a flow rate of $2 \mathrm{~mL}$ per $\min$.

Clams from the reference site (Metis beach) and from a site receiving domestic waste, Pointe-au-Père $\left(48^{\circ} 31^{\prime} \mathrm{N}\right.$, $68^{\circ} 29^{\prime} \mathrm{W}$ ), were sampled ( $\mathrm{n}=20$ per site) during five months (20 May to 4 October 2004) every two weeks, in order to measure stress responses in the natural environment and compare responses with the experimental results. Organisms were randomly sampled at low tide except on $26^{\text {th }}$ August where the Metis Beach site was partially immersed due to the tidal period. Clams sampled in the salt marsh of Pointe-au-Père near the city of Rimouski (Quebec, Canada) were sporadically exposed to a domestic sewage outfall mainly in May. High level of organic carbon $(5-10 \%)$ was detected in silt sediment of Pointe-auPère site. PAHs and oil residues were also observed in sediments [60]. Total PAHs concentrations (phenanthrene, anthracene, fluoranthene, pyrene and benzo(a)pyrene) were low and less than $3 \mu \mathrm{g} / \mathrm{g}$ dry weight.

\section{Exposure protocol}

Phytoplankton was preincubated with a complex mixture of pure PAHs containing $0.061 \mathrm{~g}$ of 2-methylphenanthrene, $0.102 \mathrm{~g}$ of naphtalene, $0.099 \mathrm{~g}$ of 2-methylnaphtalene, $0.222 \mathrm{~g}$ of phenanthrene, $0.102 \mathrm{~g}$ of anthracene, $0.314 \mathrm{~g}$ of pyrene, $0.097 \mathrm{~g}$ of benzo-(a)pyrene and $0.252 \mathrm{~g}$ of fluoranthrene dissolved in $200 \mathrm{~mL}$ of ethanol. Pure mixture of PAHs was directly added to 21 L of new phytoplankton suspension 30 minutes before its addition in the aquaria. The suspension was constantly mixed using a magnetic stirrer and bubbler. Each aquarium was supplied with new PAHs-phytoplankton mixture every 24 hours during the exposure experiment. Phytoplankton concentration was 20 million cells per $\mathrm{mL}$ and added at a rate of $2 \mathrm{~mL}$ per min giving a final concentra- 
tion of PAHs of 47,6 ng/L. Flow rate of seawater in aquaria was settled at $500 \mathrm{~mL}$ per min. PAHs concentrations chosen are representative of values of PAHs reported in the St. Lawrence - Saguenay system in suspended particulate matter and particularly in the Pointe-au-Père site. Contaminated animals consisted of clams placed in 5 aquaria $(\mathrm{n}=180)$ and fed with phytoplankton contaminated with the mixture of PAHs. Clams $(n=180)$ were placed randomly in five aquaria supplied with non contaminated phytoplankton and used as controls.

Organisms were exposed to PAHs during 9 days and the contamination was stopped for the remaining 36 days to study the biomarker responses during the depuration process. Control and contaminated clams $(n=12$ respectively) were collected randomly in each series of aquarium and organisms were replaced by additional control organisms from Metis Beach to keep the same biomass and filtration volume throughout the experimental period. PAHs were considered as the dependant variable between aquaria since conditions in each aquarium were similar and verified daily (temperature, flow rate of phytoplankton and seawater) and sediments identical in all the aquaria. Randomization of sampling in aquaria during the experimental protocol as well as the high number of clams sampled initially in Metis Beach $(\mathrm{n}=360)$ did not guarantee avoidance of pseudoreplication but certainly made it less likely [61]. Clams were sampled at day 0 (on $17^{\text {th }}$ July) just before the beginning of contamination, at days 2 (on 19th July), 5 (on 22th July) and 9 (on 26 th July) during the contamination period and at days 17 (on $3^{\text {rd }}$ August) and 45 (on $31^{\text {th }}$ August) during the depuration period. After each sampling, the organisms were placed on crushed ice and brought to the laboratory for analysis. Air was accidentally introduced under high pressure in seawater pumping and filtering system at the Pointe-auPère station at day 5 of the experiment and caused evident stress on bivalves that specific day. Therefore, data for the sampling at day 5 were removed.

\section{Immunologic analysis}

1-2 mL of haemolymph containing haemocytes was taken from the adductor muscle of clams using a $3 \mathrm{~mL}$ sterile syringe with a $23 \mathrm{G}$ needle [62] and kept on ice. The number and viability of haemocytes were evaluated microscopically, in replicates for each clam, on a Neubauer hemacytometer with blue Trypan solution. $40 \mu \mathrm{L}$ of blue Trypan $10 \%(\mathrm{w} / \mathrm{v})$ were incubated with $40 \mu \mathrm{L}$ of resuspended haemolymph during 1 minute, dead hemocytes being coloured in blue.

Phagocytosis was monitored using a microplate modified cytometric method [19,32,43,63]. Cells were washed in haemolymph and the haemocyte cell concentration was adjusted, when it was necessary with seawater, to $1,1^{*} 10^{6}$ cells $/ \mathrm{mL}$. For each organism collected in the various aquaria, $100 \mu \mathrm{L}$ of haemolymph was placed in duplicate in a 96 well microplate. A number of approximately 30 fluorescent beads, $1.716 \mu \mathrm{m}$ diameter, (Molecular Probes Inc, Eugene, OR, USA) were added for each haemocyte. After a $230 \times$ g centrifugation, samples were incubated in the dark for $18 \mathrm{~h}$ at room temperature. Following incubation, haemocytes were put on $3 \mathrm{~mL}$ of a $3 \%(\mathrm{w} / \mathrm{v})$ bovine serum albumine (BSA) gradient, mixed and centrifuged for 10 minutes at $110 \times \mathrm{g}$. Gradient medium and the free beads were removed by vacuum suction. Cells with phagocytised beads were mixed in $200 \mu \mathrm{L}$ of a solution including $50 \mathrm{~mL}$ of flow cytometric solution, Hematall (Fisher, Montreal, Canada) mixed with $100 \mathrm{mg}$ of sodium azide and $0.250 \mathrm{~mL}$ of formaldehyde. Acquisitions of phagocytic parameters were performed with a FACScan cytometer (Becton Dickinson, Immunocytochemistry Systems, Mountain View, CA, USA). Briefly, an air cooled argon laser was used to provide an excitation at $488 \mathrm{~nm}$. Fluorescent emissions emitted by the beads were collected at $520 \mathrm{~nm}$. Haemocyte populations were defined based on their forward (FSC) and right angle scatter (side scatter: SSC) properties. A total of 10000 events were acquired for each sample. The fluorescence (FL1) frequency distribution histogram of the haemocyte populations was obtained with the initial condition data analysed for two parameters: the complexity (SSC) and the cell size (FSC). Data collection and analysis were performed with the LYSIS-II program [19]. The results were expressed as the percentage of phagocytic cells having engulfed one bead and more, representing the haemocytes activity, and three beads and more as a marker of efficiency of phagocytic cells.

\section{Biochemical analysis}

For these analyses, both mesocosms (clams from aquaria) and in situ (from Pointe-au-Père and Metis Beach) organisms were used. The digestive gland of each organism was dissected and divided in two equal parts, each part was preserved and homogenised on ice in a potassium phosphate buffer $50 \mathrm{mM}$ complemented with EDTA $1 \mathrm{mM}, \mathrm{pH}$ 7.4, for CAT analysis and in $\mathrm{KCl}$ buffer $154 \mathrm{mM}$, $\mathrm{pH} 7.4$, for MDA analysis and stored at $-80^{\circ} \mathrm{C}$.

For CAT activity, homogenates were centrifuged for 5 minutes at $12000 \times \mathrm{g}$. $1 \mathrm{~mL}$ of the supernatant was incubated during 30 minutes with $10.5 \mu \mathrm{L}$ of EtOH $95 \%(w /$ v). $11.24 \mu \mathrm{L}$ of Triton X-100 10\% (w/v) was added and the samples were gently shaken for 30 seconds. All these steps were done at $4^{\circ} \mathrm{C} .50 \mu \mathrm{L}$ of each sample were then transferred in quartz spectrophotometer cuvettes with $2.95 \mathrm{~mL}$ of the potassium-phosphate-EDTA solution. The reaction was started by adding $1 \mathrm{~mL}$ of hydrogen peroxide solution $42 \mathrm{mM}$ [23]. The CAT activity was evaluated by following during 3 minutes the disappearance of hydrogen peroxide 
at a wavelengh of $240 \mathrm{~nm}$ with a UV spectrophotometer. One unit decomposes one micromole of $\mathrm{H}_{2} \mathrm{O}_{2}$ per minute at $25^{\circ} \mathrm{C}$ and $\mathrm{pH}$ 7.4. Results of CAT were expressed as $\mu \mathrm{mol}$ per min per mg proteins. Protein concentrations were determined using the Bradford method [64] at a wavelength of $595 \mathrm{~nm}$. The colour reagent was purchased from BIORAD (Mississauga, Ontario) and Bovine Serum Albumin (BSA, fraction V) from Sigma was used as the protein standard.

Concentrations of thiobarbituric acid reactive substances (TBARS) are an index of lipid peroxidation and oxidative stress. MDA is one of these substances and the method used 1,1,3,3-tetraethoxypropane as standard [65]. Briefly, $500 \mu \mathrm{L}$ of homogenates were transferred in $3 \mathrm{~mL}$ of $\mathrm{H}_{3} \mathrm{PO}_{4} 1 \%(\mathrm{w} / \mathrm{v})$ with $500 \mu \mathrm{L}$ of the KCl buffer $154 \mathrm{mM}$. All these steps were done at $4{ }^{\circ} \mathrm{C}$. Samples were incubated in a $100^{\circ} \mathrm{C}$ water bath for 45 minutes. After 5 minutes, in a cold bath $\left(10^{\circ} \mathrm{C}\right), 4 \mathrm{~mL}$ of butanol were added and samples were centrifuged at $25^{\circ} \mathrm{C}$ for 20 minutes at $1000 \times \mathrm{g}$. The supernatant was transferred in tubes and the MDA formed was estimated at 532, 508 and $556 \mathrm{~nm}$ (corrected absorbance $\left.=A b_{532}-A b_{508}+A b_{556}\right)$. Results were expressed as nmol per g wet tissue.

\section{Statistical analysis}

The results were analysed using SigmaStat for Windows version 3.11 (Systat software ${ }^{\circledR} 2004$ ). Normality of distribution of data (Kolmogorov-Smirnov test) and homogeneity of variance (Levene Median Test) were tested. A one way analysis of variance (ANOVA) was performed to determine differences in mean values among the two groups when the normality test passed. A non-parametric (Kruskall-Wallis) one way ANOVA was performed on data depending when the normality test failed. Significance was defined at $\mathrm{P}<0,05$, and when significant differences were found, a Multiple Pairwise Comparison (Tukey's test) was used to isolate the different groups (significance set at $\mathrm{P}<0,05)$. Finally, a linear regression analysis with Pearson's correlation coefficient was performed to illustrate possible relations between the PAH exposure period and the biomarkers used.

\section{Conclusion}

In summary, the exposure to a mixture of PAHs at a level normally found in coastal environment under a low contamination stress, affected processes of haemocyte production as illustrated by the immunological markers used. At the end of the experiment, recovery was observed for all the immunological parameters measured. For the measures of the oxidative stress with CAT and MDA, no significant differences were observed between control and contaminated clams, attesting a normal physiological state in spite of the bioaccumulation observed during the contamination period. However, results on the immuno- logical markers showed that Mya arenaria was able to transform PAHs used for this experiment efficiently since after the exposure has been stopped, the levels of all these parameters began to return to normal conditions. The results of MDA and CAT observed in mesocosms, as well as those observed from Pointe-au-Père clams, attest that at the PAHs concentration of $47,6 \mathrm{ng} / \mathrm{L}$, no oxidative stress occurs. The only physiological change occurred at the level of the immune system.

It is therefore of first importance to determine the sensitivity of immune endpoints as good markers of exposure to PAHs in bivalves. Considering antioxidant responses induced following an exposure to PAHs, it is also crucial to study interaction with immune competence to determine relationship (cause to effect) between exposure to PAHs, antioxidant responses and consequences on immune competence.

This work is a contribution to a crucial need to understand physiological responses of marine invertebrates facing toxicant challenges and eventually a decrease of their health conditions and survival rate. Moreover, Mya arenaria represents one of the first levels of the trophic way. It is a good indicator species to insure better understanding, in complement with other trophic level contamination studies, of the consequence of a low concentration $\mathrm{PAH}$ contamination through the trophic way. The responses of clams during the exposure period to PAHs was estimated but the more interesting responses were those of the biomarkers during the 36 day depuration period following exposure, attesting the strong recovery of immune competence.

\section{Abbreviations}

BSA: bovine serum albumin; CAT: catalase; EDTA: Ethylene glycol-bis(2-aminoethyl-ether)-N, N, N', N'-tetraacetic acid; EtOH: ethanol; MDA: malondialdehyde; $\mathrm{PAH}$ : polycyclic aromatic hydrocarbons; ROS: reactive oxygen species; TBARS: thiobarbituric acid reactive substances.

\section{Competing interests}

The authors declare that they have no competing interests.

\section{Authors' contributions}

NP participated in the design, collected data, performed data analysis and drafted the manuscript. SGC and PR participated in the data collection. JP, EP and MF conceived the study, participated in its design and coordination. JP and MF contributed to the draft of the manuscript. JP read the draft and suggested corrections to NP. All authors read and approved the final manuscript.

\section{Acknowledgements}

The authors thank all the crew who worked on the project at the Institut des Sciences de la Mer de Rimouski (ISMER/UQAR) and at the Institut 
Armand-Frappier (IAF/INRS). Financial support has been provided by the Natural Sciences and Engineering Research Council of Canada (Collaborative Research and Development Program), private partner ALCAN Ltée, the Réseau de Recherche en Ecotoxicologie du Saint-Laurent (CIRÉ), the Canada Research Chair in Environmental immunotoxicology and QuébecOcéan network.

\section{References}

I. Mc Elroy AE, Farrington JW, Teal JM: Bioavailability of polycyclic aromatic hydrocarbons in the aquatic environment. In Metabolism of Polycyclic Aromatic Hydrocarbons in the Aquatic Environment Edited by: Varanasi U. Boca Raton: CRC Press; 1989:1-39.

2. Grundy MM, Moore MN, Howell SM, Ratcliffe NA: Phagocytic reduction and effects on lysosomal membranes by polycyclic aromatic hydrocarbons in haemocytes of Mytilus edulis. Aquat Toxicol 1996, 34:273-290.

3. Grundy MM, Ratcliffe NA, Moore MN: Immune inhibition in marine mussels by polycyclic aromatic hydrocarbons. Mar Environ Res 1996, 42: 187-190.

4. Gauthier-Clerc S, Pellerin J, Blaise C, Gagné F: Delayed gametogenesis of Mya arenaria in the Saguenay Fjord (Canada) : a consequence of endocrine disruptors? Comp Biochem Physiol C Toxicol Pharmacol 2002, 13 I (4):457-467.

5. Wootton EC, Dyrynda EA, Pipe RK, Ratcliffe NA: Comparisons of PAH-induced immunomodulation in three bivalve molluscs. Aquat Toxicol 2003, 65:13-25.

6. Moore M: Cellular responses to Polycyclic Aromatic Hydrocarbons and phenobarbital in Mytilus edulis. Mar Environ Res 1979, 2:255-263.

7. Nott JA, Moore MN, Mavin LJ, Ryan KP: The fine structure of lysosomal membranes and endoplasmic reticulum in the digestive cells of Mytilus edulis exposed to anthracene and phenanthrene. Mar Environ Res 1985, 17:226-229.

8. Moore MN, Livingstone DR, Widdows J, Lowe DM, Pipe RK: Molecular, cellular and physiological effects of oil-derived hydrocarbons on molluscs and their use in impact assessment. Philos Trans R Soc London Ser B 1987, 316:603-623.

9. Livingstone DR, Lips F, Garcia-Martinez P, Pipe RK: Antioxidant enzymes in the digestive gland of the common mussel Mytilus edulis. Mar Biol 1992, I I 2:265-276.

10. Krishnakumar PK, Casillas E, Varanesi U: Cytochemical responses in the digestive tissue of Mytilus edulis complex exposed to microencapsuled PAHs or PCBs. Comp Biochem Physiol C 1997, II8:11-18.

II. Viarengo A, Moore MN, Pertica M, Mancinelli G, Accomando R: A simple procedure for evaluating the protein degradation rate in mussel tissues and its application in a study of phenanthrene effects on protein catabolism. Comp Biochem Physiol B 1992, 103:27-32.

12. Livingstone DR, Lemaire P, Matthews AA, Peters LD, Porte C, Fitzpatrick PJ, Forlin L, Nasci C, Fossato V, Wootton N, Goldfarb P: Assessment of the impact of organic pollutants on goby (Zostericessor ophiocephalus) and mussel (Mytilus galloprovincialis) from the Venice lagoon, Italy: Biochemical studies. Mar Environ Res 1995, 39:235-240.

13. Cossu C, Doyotte A, Babut M, Exinger A, Vasseur P: Antioxidant biomarkers in freshwater bivalves, Unio tumidus, in response to different contamination profiles of aquatic sediments. Ecotoxicol Environ Saf 2000, 45:106-121.

14. Camus L, Birkely SR, Jones MB, Borseth JF, Grosvik BE, Gulliksen B, Lonne OJ, Regoli F, Depledge MH: Biomarker responses and PAH uptake in Mya truncata following exposure to oil-contaminated sediment in an Arctic fjord (Svalbard). Sci Total Environ 2003, 308:221-234.

15. Cheung CCC, Zheng G], Li AMY, Richardson BJ, Lam PKS: Relationships between tissue concentrations of polycyclic aromatic hydrocarbons and antioxidative responses of marine mussel, Perna viridis. Aquat Toxicol 200I, 52:189-203.

16. Cheung CCC, Siu WHL, Richardson BJ, De Luca-Abbott SB, Lam PKS: Antioxidant responses to benzo-(a)-pyrene and aroclor 1254 exposure in the green-lipped mussel, Perna Viridis. Environ Pollut 2004, I 28:393-403.

17. DiGiulio RT, Weashburn PC, Wenning RJ, Winston GW, Jewell CS: Biochemical responses in aquatic animals : A review of determinants of oxidative stress. Environ Toxicol Chem 1989 , 8:1103-II23

18. Livingstone DR, Garcia-Martinez P, Michel M, Ribera D, Winston GW: Oxyradical production as a pollution-mediated mechanism of toxicity in the common mussel, Mytilus edulis, and other molluscs. Funct Ecol I990, 4:4|5-424.

19. Brousseau P, Payette Y, Blakley B, Boermans H, Flipo D, Tryphonas $\mathrm{H}$, Fournier M: Manual of immunological Methods Boston: CRC Press; 1998.

20. Fournier M, Cyr D, Blakley B, Boermans H, Brousseau P: Phagocytic activity as a biomarker of immunotoxicity in wildlife species exposed to environmental xenobiotics. Am Zool 2000, 40:4I2-420.

21. Pellerin-Massicotte J: Oxidative processes as indicators of chemical stress in marine bivalves. J Aquat Ecosyst Health 1994, 3:101-III.

22. Cossu C, Doyotte A, Jacquin M-C, Vasseur P: Biomarqueurs du stress oxydant chez les animaux aquatiques. In Biomarqueurs en Ecotoxicologie Edited by: Lagadic L, Caquet T, Amiard J-C, Ramade F. Paris: Masson; 1997:149-163.

23. Pellerin-Massicotte J: Influence of elevated temperature and air-exposure on MDA levels and catalase activities in digestive glands of the blue mussel (Mytilus edulis). J Rech Océanogr 1997, 22:91-98.

24. DiGiulio RT, Habig C, Gallagher EP: Effects of Black Rock Harbor sediments on indices of biotransformation, oxidative stress and DNA integrity in channel catfish. Aquat Toxicol 1993, 26:I-22.

25. Livingstone DR, Lemaire P, Matthews AA, Peters L, Bucke D, Law RJ: Prooxidant, antioxidant and 7-ethoxyresorufin o-deethylase (EROD) activity responses in liver of dab (Limanda limanda) exposed to sediment contaminated with hydrocarbons and other chemicals. Mar Pollut Bull 1993, 26:602-606.

26. Tremblay R, Pellerin-Massicotte J: Effects of the tidal cycle on lysosomal membrane stability in the digestive gland of Mya arenaria and Mytilus edulis. Comp Biochem and Physiol A 1997, II 7:99-104.

27. Regoli F: Total oxyradical scavenging capacity (TOSC) in polluted and translocated mussels : a predictive biomarker of oxidative stress. Aquat Toxicol 2000, 50:35I-36I.

28. Viarengo A, Canesi L, Pertica M, Poli G, Moore MN, Orunesu M: Heavy metals effects on lipid peroxidation in the tissues of Mytilus galloprovincialis. Comp Biochem Physiol C 1990, 97:37-42.

29. Garcia-Martinez P, Winston GW, Metash-Dickey C, O'Hara SCM, Livingstone DR: Nitrofurantoin-stimulated reactive oxygen species production and genotoxicity in digestive gland microsomes and cytosol of the common mussel Mytilus edulis. Toxicol Appl Pharmacol 1995, I 3 I:332-34I.

30. George SG: Heavy metal detoxication in Mytilus edulis kidney: an in vitro study of $\mathrm{Cd}$ - and $\mathrm{Zn}$-binding to isolated tertiary lysosomes. Comp Biochem Physiol C 1983, 76:59-65.

31. Wong S, Fournier M, Coderre D, Banska W, Krzystyniak K: Environmental Immunotoxicology. In Animal Biomarkers as Pollution Indicators Edited by: Peakall D. London/New York: Chapman and Hall; 1992:167-189.

32. Fournier M, Pellerin J, Lebeuf M, Brousseau P, Morin Y, Cyr D Effects of exposure of Mya arenaria and Mactromeris polynyma to contaminated marine sediments on phagocytic activity of haemocytes. Aquat Toxicol 2002, 59:83-92.

33. Auffret M: Bivalves as model for marine immunotoxicology. Investigative immunotoxicology 2005:29-48.

34. Anderson RS, Paynter KT, Burreson EM: Increased reactive oxygen species intermediate production by haemocytes withdraw from Crassostrea virginica infected with Perkinsus Marinus. Biol Bull I992, I 83:476-48I.

35. Coles JA, Farley SR, Pipe RK: Effects of fluoranthene on the immunocompetence of the common marine mussel, Mytilus edulis. Aquat Tox 1994, 30:367-379.

36. Suresh K, Mohandas A: Hemolymph acid phosphatase activity pattern in copper-stressed bivalves. J Invert Pathol 1990, 55: II8- 125

37. Sami S, Faisal M, Huggett RJ: Alterations in cytometry characteristics of hemocytes from the American Oyster Crassostrea virginica exposed to Polycyclic Aromatic hydrocarbon (PAH) contaminated environment. Mar Biol 1992, I I 3:247-252. 
38. Cheng TC: In vivo effects of heavy metals on cellular defense mechanisms of Crassostrea virginica: total and differential cell counts. J Invert Pathol 1988, 5 I:207-2 I4.

39. Renwrantz L: Internal defense system of Mytilus edulis. 1990. In Neurobiology of Mytilus edulis Edited by: Stefano GB. Manchester: Manchester University Press; 1990:256-274.

40. Gauthier-Clerc S, Pellerin J, Fournier M, Amiard J-C: Immunological and biochemical responses in Mya arenaria (Mollusca Bivalvia) exposed in vivo to estradiol- I 7 $\beta$. Comp Biochem Physiol C Toxicol Pharmacol 2006, I44(3):228-234.

4I. Anderson RS, Giam C, Ray L, Tripp MR: Effects of environmental pollutants on immunological competency of the clam, Mercenaria mercenaria: impaired bacterial clearance. Aquat Toxicol I981, I:187-195.

42. Mc Cormick-Ray MG: Haemocytes of Mytilus edulis affected by Prudhoe Bay crude oil emulsion. Mar Environ Res 1987 22:107-122.

43. Brousseau P, Pellerin J, Morin Y, Cyr D, Blakley B, Boermans H, Fournier M: Flow cytometry as a tool to monitor the disturbance of phagocytosis in the clam Mya arenaria haemocytes following in vitro exposure to heavy metals. Toxicology 2000 I 42: | 45-I 56.

44. Bouchard N, Pelletier E, Fournier M: Effects of butyltin compounds on phagocytic activity of haemocytes from three marine bivalves. Environ Toxicol Chem 1999, 18:519-522.

45. Sauvé S, Brousseau P, Pellerin J, Morin Y, Sénécal L, Goudreau P, Fournier M: Phagocytic of marine and freshwater bivalves : in vitro exposure of haemocytes to metals $(\mathrm{Ag}, \mathrm{Cd}, \mathrm{Hg}$ and $\mathrm{Zn}$ ). Aquat Toxicol 2002, 58:189-200.

46. Coles JA, Farley SR, Pipe RK: Alteration of the immune response of the common marine mussel Mytilus edulis resulting from exposure to cadmium. Dis Aquat Organ 1995, 22:59-65.

47. Ribera D, Narbonne J-F, Michel X, Livingstone DR, O'Hara S: Responses of antioxidants and lipid peroxidation in mussels to oxidative damage exposure. Comp Biochem Physiol C 1991, I00:177-18I.

48. Winston GW, DiGiulio RT: Prooxidant and antioxidant mechanisms in aquatic organisms. Aquat Toxicol 1991, 19:137-191.

49. Rouleau C, Pelletier É, Richard P: Distribution of radioactive pyrene in Mya arenaria. SETAC North America 27th Annual Meeting. 5-9 November 2006; Montréal .

50. Aust SD, Morehouse LA, Thomas CE: Role of metals in oxygen radical reactions. Free Radical Biol Med 1985, I:3-25.

5I. Johnson LL, Collier TK, Stein JE: An Analysis in support of sediment quality thresholds for polycyclic aromatic hydrocarbons (PAHs) to protect estuarine fish. Aquatic Conserv: Mar Freshw Ecosyst 2002, 1 2:517-538.

52. Saint-Louis R, Pelletier E: Concept of xenobiotics metabolism at the ecosystem level: application to hydroxypyrene in cold marine waters. SETAC North America 25th Annual Meeting: 14-18 November 2004; Portland .

53. Garnerot F, Pellerin J, Blaise C, Mathieu M: Immunohistochemical localization of serotonin (5-hydroxytryptamine) in the gonad and digestive gland of Mya arenaria (Mollusca: Bivalvia). Gen Comp Endocrinol 2006, 149:278-284.

54. Lemly AD: Role of season in aquatic hazard assessment. Environ Monit Assess 1997, 45:89-98.

55. Coustau C, Combes C, Maillard C, Renaud F, Delay B: Prosorhynchus squamatus 1990. (Trematoda) parasitosis in the Mytilus edulis-Mytilus galloprovincialis complex : specificity and hostparasite relationships. In Pathology in Marine Science Edited by: Perkins FO, Cheng TC. New-York: Academic Press; 1990:291-298.

56. Coustau C, Robbins I, Delay B, Renaud F, Mathieu M: The parasitic castration of the mussel Mytilus edulis by the trematode parasite Prosorhynchus squamatus: specificity and partial characterization of endogenous and parasite-induced anti-mitotic activities. Comp Biochem Physiol A 1993, I 04:229-233.

57. Gagné F, Blaise C, Pellerin J, Fournier M, Durand MJ, Talbot A: Relationships between intertidal clam population and health status of the soft-shell clam Mya arenaria in the St. Lawrence Estuary and Saguenay Fjord (Québec, Canada). Environ Int 2008, 34:30-43.

58. Beal BF: Relative importance of predation and intraspecific competition in regulating growth and survival of juveniles of the soft-shell clam, Mya arenaria L., at several spatial scales. J Exp Mar Biol Ecol 2006, 336(SuppI I): I-I7.
59. Kube J: Spatial and temporal variations in the population structure of the soft-shell clam Mya arenaria in the Pomeranian Bay (southern Baltic Sea). J Sea Res 1996, 35(Suppl 4):335-344.

60. Pelletier E, Desbiens I, Sargian P, Cote N, Curtosi A, St-Louis R: Présence des hydrocarbures aromatiques polycycliques (HAP) dans les compartiments biotiques et abiotiques de la rivière et du fjord du Saguenay. J Water Sci in press.

61. Quinn GP, Keough MJ: Experimental Design and Data Analysis for Biologists Cambridge: Cambridge University Press; 2002.

62. Pipe RK, Coles JA, Thomas ME, Fossato VU, Pulsford AL: Evidence for environmentally derived immunomodulation in mussels from the Venice lagoon. Aquat Toxicol 1996, 32:59-73.

63. Fournier M, Pellerin J, Clermont Y, Morin Y, Brousseau P: Effects of in vivo exposure of Mya arenaria to organic and inorganic mercury on phagocytic activity of haemocytes. Toxicology 200I, I6 I(Suppl 3):20I-2II.

64. Bradford MM: A rapid and sensitive method for the quantitation of microgram quantities of protein utilizing the principle of protein dye binding. Anal Biochem 1976, 72:248-254.

65. Miller D, Aust SD: Studies of ascorbate-dependent, iron-catalyzed lipid peroxidation. Arch Biochem Biophys I 989, 27 I I I 3- I I 9.

\section{Publish with ChemistryCentral and every} scientist can read your work free of charge

"Open access provides opportunities to our

colleagues in other parts of the globe, by allowing

anyone to view the content free of charge."

$$
\text { W. Jeffery Hurst, The Hershey Company. }
$$

- available free of charge to the entire scientific community

- peer reviewed and published immediately upon acceptance

- cited in PubMed and archived on PubMed Central

- yours - you keep the copyright

Submit your manuscript here:

http://www.chemistrycentral.com/manuscript/

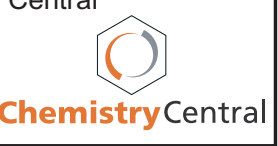

